Mеталлофиз. новейшие технол. / Metallofiz. Noveishie Tekhnol. (C) 2016 ИМФ (Институт металлофизики 2016, т. 38, № 2, сс. 267-275 / DOI: 10.15407/mfint.38.02.0267 им. Г. В. Курдюмова НАН Украины) Оттиски доступны непосредственно от издателя

Фотокопирование разрешено только

Напечатано в Украине.

в соответствии с лицензией

PACS numbers: 42.79.Vb, 68.35.Gy, 68.35.Np, 68.37.Ps, 78.66.Bz, 81.15.Ef, 89.20.Ff

\title{
Optical Disc for Long-Term Data Storage Based on Chromium Film
}

\author{
I. V. Gorbov, D. Yu. Manko, A. A. Kryuchyn, Zichun Le",***, \\ Minglei $\mathrm{Fu}^{*, * * *}$, and A. V. Pankratova
}

Institute for Information Recording, N.A.S. of Ukraine, 2 M. Shpaka Str.,

03113 Kyiv, Ukraine

"Institute of Optical Engineering, Zhejiang University of Technology, 310023 Hangzhou, China

*:Yiwu Institute of Science and Technology, Zhejiang University of Technology, 322001 Yiwu, China

The applicability of the $\mathrm{Ag}, \mathrm{Au}, \mathrm{Al}$, and $\mathrm{Cr}$ films as the reflective layer of optical discs for long-term data storage is investigated. Thin metal films are obtained on glass substrate by the method of vacuum thermal deposition. Their adhesive properties are revealed. As shown, a chromium film is characterized by the best adhesion to the glass substrate among all investigated ones. Optical disc for long-term storage is proposed. The information on disk is recorded directly on the reflective metal film. The information on the positive photoresist layer is recorded according to already existed CD standard using laserburning station. Then, the mask for following chemical etching of chromium film is created. Analysis of morphology of recorded pits proves suitability of the long-term data storage disc to existing standards. Chromium optical disc created in this way is successfully read in a standard DVD player.

Key words: long-term data storage, optical disc, WORM, chromium film, adhesion.

Досліджено можливість використання плівок $\mathrm{Ag}, \mathrm{Au}, \mathrm{Al}$ и $\mathrm{Cr}$ в якості відбивального шару оптичних дисків для довготермінового зберігання інформації. Тонкі металеві плівки були одержані на поверхні скляного під-

Corresponding author: Ivan Vasil'evich Gorbov

E-mail: ivan-gorbov@list.ru

Please cite this article as: I. V. Gorbov, D. Yu. Manko, A. A. Kryuchyn, Zichun Le, Minglei Fu, and A. V. Pankratova, Optical Disc for Long-Term Data Storage Based on Chromium Film, Metallofiz. Noveishie Tekhnol., 38, No. 2: 267-275 (2016)

(in English), DOI: 10.15407/mfint.38.02.0267. 
ложжя методою вакуумного термічного розпорошення; було досліджено їхні адгезійні властивості. Показано, що найкращу адгезію до скляного підложжя серед обраних плівок мають плівки хрому. Запропоновано оптичний диск для довготермінового зберігання даних, інформацію в якому записано безпосередньо на відбивальній металевій плівці у форматі стандартного оптичного диску. В шарі позитивного фоторезисту на станції лазерного запису в форматі CD були записані дані. Таким чином було одержано маску для наступного хемічного щавлення плівки хрому. Аналіза морфології записаних пітів показала їх відповідність стандарту. Створений хромовий диск для довготермінового зберігання інформації було успішно відтворено на стандартному програвачі DVD-дисків.

Ключові слова: довготермінове зберігання інформації, оптичний диск, WORM, металева плівка, адгезія.

Исследована возможность применения плёнок $\mathrm{Ag}, \mathrm{Au}, \mathrm{Al}$ и $\mathrm{Cr}$ в качестве отражающего слоя оптических дисков для долговременного хранения информации. Тонкие металлические плёнки были получены на поверхности стеклянной подложки методом вакуумного термического напыления; изучены их адгезионные свойства. Показано, что наилучшей адгезией к стеклянной подложке среди исследуемых плёнок обладает плёнка хрома. Предложен оптический диск для долговременного хранения данных, информация в котором записана непосредственно на отражающей металлической плёнке в формате стандартных оптических дисков. В слое позитивного фоторезиста на станции лазерной записи в формате CD были записаны данные. Таким образом, была получена маска для последующего химического травления плёнки хрома. Анализ морфологии записанных питов показал их соответствие стандарту. Созданный хромовый диск для долговременного хранения информации был успешно воспроизведён на стандартном проигрывателе DVD-дисков.

Ключевые слова: долговременное хранение информации, оптический диск, WORM, металлическая плёнка, адгезия.

(Received September 17, 2015; in final version, October 27, 2015)

\section{INTRODUCTION}

The task of reliable long-term storage of information has always been one of the most important tasks of human development [1,2]. The long-term data storage must correspond to following demands: longevity, capacity, viability, non-obsolescence, and cost [3]. Widespread optical discs have sufficient capacity and low price. However, they cannot provide longevity and viability due to following factors: nonstability and not sufficient mechanical strength of a substrate, and bad adhesion between layers. As well known, interference structures made of different kind of materials may change optical properties of a compact disc (CD) while external condition of storage varied (temperature, 
humidity, etc.) [3, 4]. These factors cause losses of recorded data.

In order to readout a signal from the optical disc, its surface must be covered with a reflective metal layer. Such reflective layer must be characterized by high adhesion to the substrate material, has a sufficient light reflectance and do not change their optical and mechanical properties over time [2]. The most manufacturers of optical discs use polycarbonate substrate with $\mathrm{Al}$ film reflective layer deposited onto it [4]. Some producers deposit Ag or Au film layer on a surface of an optical disc in order to increase its durability. However, above-mentioned metal films are characterized by a very low adhesion to a polycarbonate substrate. That is why joining of metallic reflective film and a substrate is provided only by using protective specific lacquer layer. Note that partial or complete removal of reflective layer takes place in the case of damage of the protective lacquer.

Information may be stored in the form of micro-relief on the surface of the transparent high-stable inorganic substrates, which are characterized by comparable high resistance to chemically active environment and ability to withstand relatively high temperatures [2]. Thus, optical carriers for long-term data storage based on sodium and silica glasses or sapphire were described in many publications [4-7]. The principle of digital data recording on optical media for long-term data storage is based on the similar technology as used to create a master-disc for mass production of optical media; its data format is fully consistent with standard CD and DVD. However, such high resistance of substrate results in relatively complex and costly methods of information recording based on ion-beam etching or femtosecond pulse laser using.

An alternative method for long-term data storage is the ablative recording, during which the recording material is evaporated by the laser radiation. This type of information recording is used in many types of WORM (Write Once Read Many) media. Disadvantage of such data carriers is thermal sensitivity of recording layer [8]. Therefore, it is reasonable to write directly on the metal layer. Namely, we propose to combine reflective and recording layers in a single layer, which should have good adhesion to the substrate material. This may improve the overall reliability of the optical recording medium and reduce the probability of separation during its usage.

Therefore, the first objective of work is to design the optical media for long-term storage with information recorded directly onto metal film which has high adhesion to the glass substrate. The second objective is that the information must be readout on a usual optical disc player.

\section{EXPERIMENTAL}

In order to achieve these objectives, it is necessary to obtain metal 
films with the same thickness, which are used or may be used for optical discs fabricating and compare their adhesion to glass substrate surface. High adhesion receives in metal films, which are actively oxidized, when deposited on a glass substrate, such as chromium, magnesium, zirconium and others [9, 10]. Then, $\mathrm{Ag}, \mathrm{Au}, \mathrm{Al}$ and $\mathrm{Cr}$ metal films have been chosen for further investigations. One of the main reasons for good adhesion is careful chemical treatment of substrates before film deposition [9]. Sodium glass substrates were cleaned successively in an ultrasonic bath, liquid acetone, and isopropanol then processed into high-voltage discharge in vacuum chamber. Metal $\mathrm{Ag}, \mathrm{Au}$, $\mathrm{Al}$ and $\mathrm{Cr}$ films were deposited by thermal evaporation in similar conditions from resistive heated boat at temperature of substrate $T=20^{\circ} \mathrm{C}$ and pressure $P=10^{-3} \mathrm{~Pa}$. Thickness of obtained films was closed to $60 \mathrm{~nm}$ and was controlled during deposition by measuring of light absorption. Adhesion of films was determined by the required load to scratch coating [9]. The adhesion of each sample was measured immediately after removal from the thermal annealing chamber and periodically during 600 hours. Between measurements, the samples were stored in a desiccator.

Proposed metal film must be characterized by at least $20 \%$ reflectance for reliable reading [4]. Performed studies of adhesion of selected metal films showed that Cr film is most applicable for glass optical disk for long-term data storage. Then, the question of applicability of $\mathrm{Cr}$ thin film for optical disc production requires additional detailed study of its reflection. Optical properties of metal film significantly depend on its structure affected by film thickness and substrate temperature during deposition. Then, Cr films with different thicknesses were additionally obtained on unheated and heated glass substrates for further reflection studies. Reflection were obtained using modified LEF 3M-1 ellipsometer. The ellipsometric measurements were carried out with $\lambda=632.8 \mathrm{~nm}$ wavelength [11]. The angle of incidence of the light at the sample surface was close to the principal angle. The diameter of the incident light beam was $3.5 \mathrm{~mm}$. The reflection was calculated from the values of the ellipsometric parameters [11].

Positive organic photoresist 'Shipley 1805' has been used for making a mask. Films of the photoresist were obtained using a centrifuge with the rotation speed about $2800 \mathrm{rpm}$ and then they were annealed at $T=90^{\circ} \mathrm{C}$ during one hour. The thickness of the composite film was $150 \mathrm{~nm}$, which was enough for the process of chemical etching. Information layer on the surface of the disc was patterned using master disc laser burning station [2]. Chemical etching of chromium film was performed using $20 \%$ solvent of $\mathrm{CeSO}_{4}$, which was poured on a substrate rotating at $100 \mathrm{rpm}$ for 2 minutes. After etching, photoresist was removed using alkaline solution of $2 \% \mathrm{KOH}$ for 10 hours. Testing of reading-out quality of recorded glass disc was performed using Nero 
7.0 CD-DVD speed tool. Atomic force microscopy was performed using atomic force microscope of NanoScope, Dimension 3000 TM.

\section{RESULTS AND DISCUSSIONS}

Results of critical load of different metallic films on sodium glass are presented in Fig. 1. It was found that such metals as $\mathrm{Au}$ and $\mathrm{Ag}$ are characterized by weak adhesion to a glass substrate and can be easily removed from it under weak required load (Fig. 1). Note that adhesion of $\mathrm{Au}$ does not change with a time. This is being caused because $\mathrm{Au}$ is noble metal and hardly can be oxidized, so it must be characterized by relatively poor adhesion to the glass surface [9].

Chromium is well known material, which is characterized by good adhesion to silica glass as it seen from Fig. 1. Adhesion between Cr film and a glass substrate reaches high values immediately after film prepared and exceeds $100 \mathrm{~g}$. During the next 100-200 hours, critical load of $\mathrm{Cr}$ film towards glass increases and reaches a maximum of $500 \mathrm{~g}$. This value is more than 50 times higher than for Ag film deposited on glass substrate.

It must be noted that chromium film was not removed completely by testing set. Thus, the Cr film can be used to create media for long-term storage. The use of the protective layer in this case is only necessary for protection against impurities.

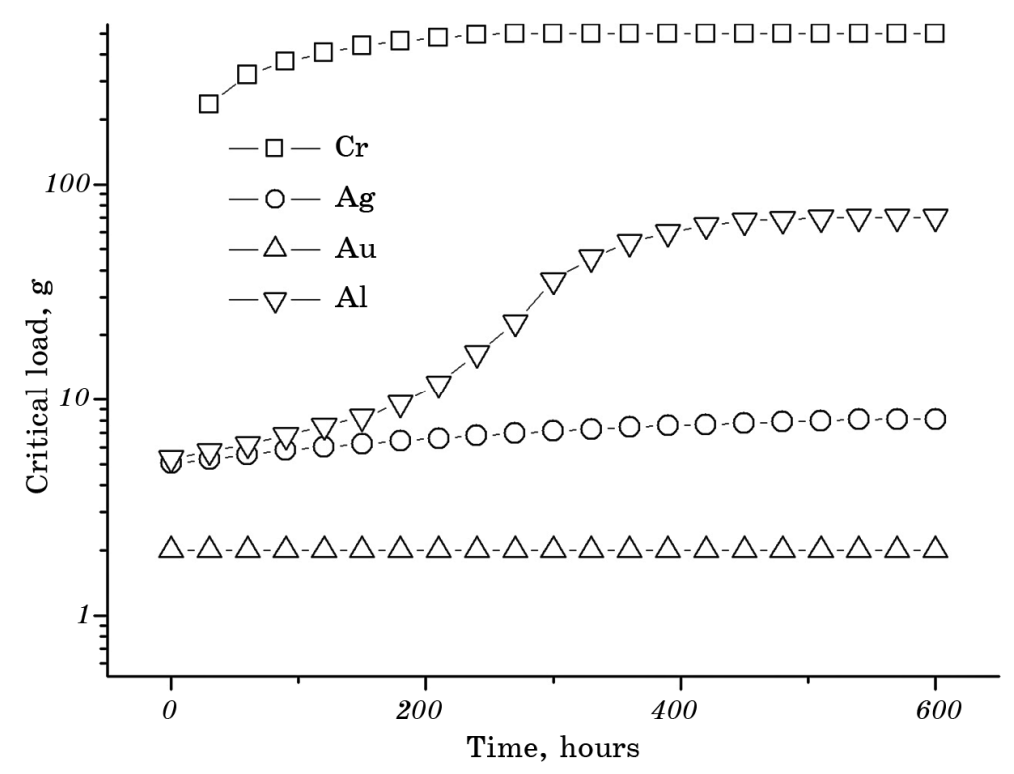

Fig. 1. Critical load of $\mathrm{Ag}, \mathrm{Au}, \mathrm{Cr}$ and $\mathrm{Al}$ metal films to glass substrates versus time. 
Reflection of Cr films with different thickness obtained on unheated and heated glass substrates was studied as well (Fig. 2). Revealed data demonstrate that reflection value level varies from $30 \%$ to $60 \%$. Films deposited on the heated substrate are characterized by higher reflection. However, difference between films obtained on the surface of substrates with $100^{\circ} \mathrm{C}$ and $180^{\circ} \mathrm{C}$ is not significant. All films with thickness more than $30 \mathrm{~nm}$ demonstrates values of reflection equal $40 \%$ and higher that is sufficient for long-term data storage discs.

Deposited Cr film is used not only as a reflective layer, but also as a recording one. Thereby, next step was chemically etching of Cr covered samples. Thickness of $\mathrm{Cr}$ thin film was $\cong 50 \mathrm{~nm}$. The result is shown on Fig. 3. Atomic force microscopy revealed that width of a pit was $\cong 0.8 \mu \mathrm{m}$; a track pitch was $\cong 1.6 \mu \mathrm{m}$. In addition, one can see on the picture small white spots, which obviously are connected with remains of photoresist. A pit has a good rectangular shape, which is reproducible for different pits (Fig. 4).

Test quality reading sectors from the surface resulting CD (Fig. 5) showed that $99.8 \%$ of sectors can be red without any error, $0.2 \%$ have errors associated. These errors are concentrated in only one region of the disc, which is at the start of the recording, so it could be caused by mechanical scratches on photoresist mask. This means that the increased width of the pits for this type of record does not have a significant impact on the quality of the recording.

The maximum speed-reading received $\mathrm{CD}$ was $8,04 \mathrm{X}$ corresponding to $1200 \mathrm{~kb} / \mathrm{s}$. Thus, the developed method of manufacture was set up optical media for long-term storage of information in a standard for-

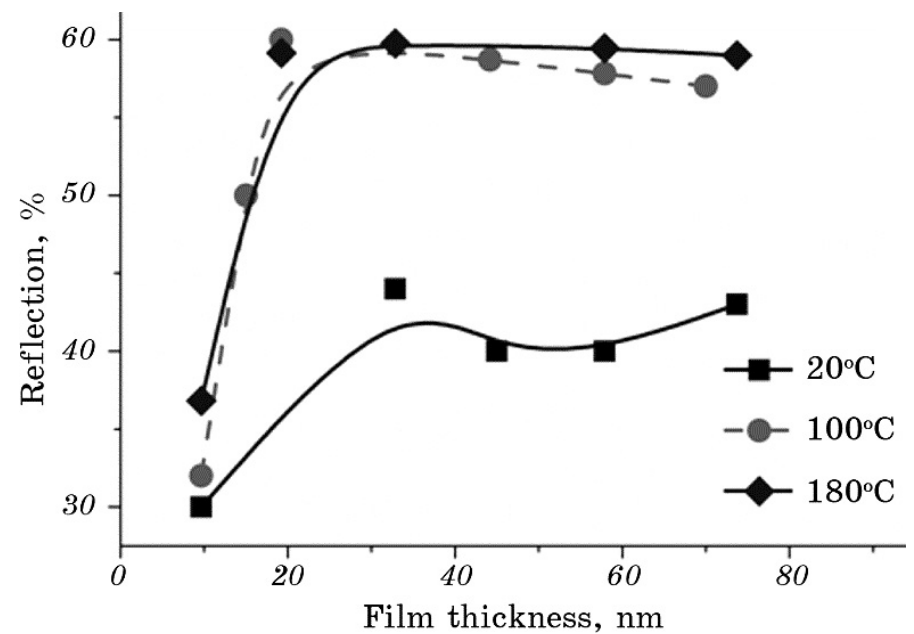

Fig. 2. Reflection of chromium films deposited on glass substrates with different temperatures and thickness. 
mat CD that played on standard CD players and DVD, and the error rate in the signal reproduction, which does not exceed the maximum allowed level.

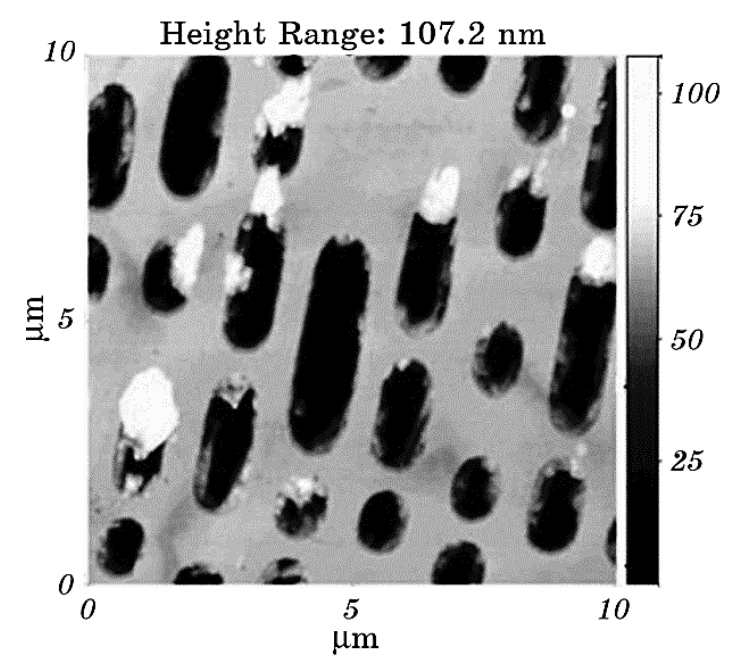

Fig. 3. AFM image of chemically etched Cr optical disc.

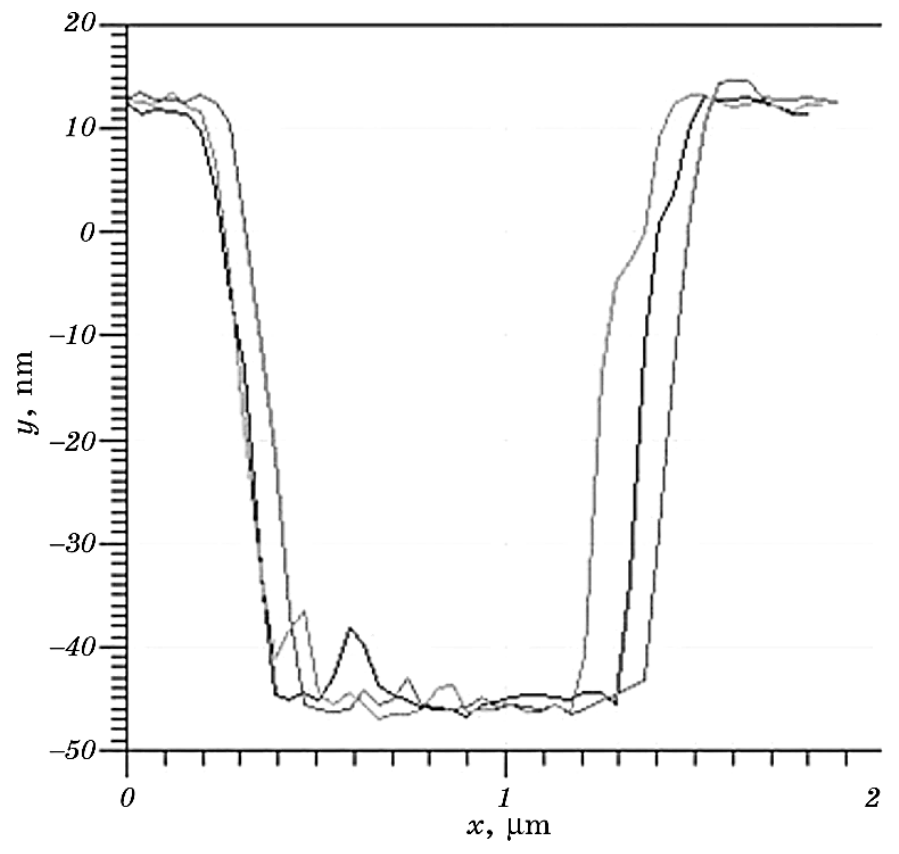

Fig. 4. Pits' cross section. 


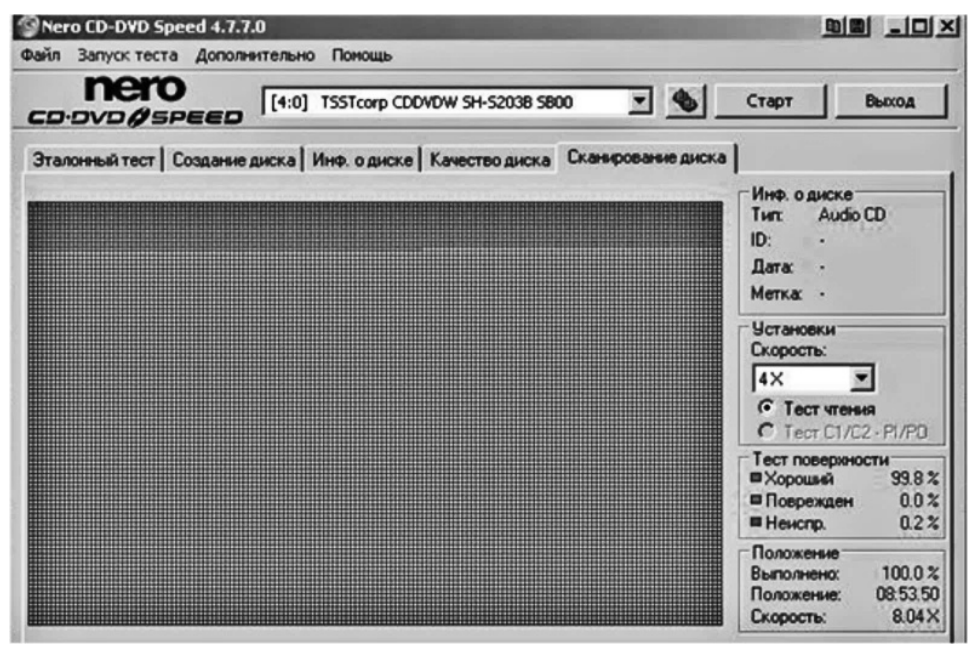

Fig. 5. Quality of written sectors.

\section{CONCLUSIONS}

We proposed using $\mathrm{Cr}$ film as the reflective layer of the optical recording medium for long-term data storage. It was shown that the adhesion of the chromium film might exceed more than 50 times that of the $\mathrm{Al}$ film.

It was shown that recording information in the film of $\mathrm{Cr}$ could be fulfilled by means of chemical etching. The possibility of combining the recording and reflective layers of optical media for long-term data storage was revealed.

Obtained chromium WORM disc for long-term data storage with $0.8 \mu \mathrm{m}$ a pit width, $0.8 \mu \mathrm{m}$ track pitch and $50 \mathrm{~nm}$ a pit depth was successfully read by standard DVD-player with $0.2 \%$ of errors.

The results of investigations presented in this article were obtained due to the support of the High-end Foreign Expert Program of China No. GDT20153300054.

\section{REFERENCES}

1. V. Petrov, A. Kryuchyn, and I. Gorbov, Proc. SPIE, 8011: 80112J (2011).

2. V. V. Petrov, V. M. Puzikov, A. A. Kryuchyn, and I. V. Gorbov, Nanosistemi, Nanomateriali, Nanotehnologii, 7, No. 3: 825 (2009) (in Russian).

3. R. Harvey, Preserving Digital Materials (Hawthorne: Walter de Gruyter: 2012).

4. I. V. Gorbov and V. O. Belyakovsky, Data Recording, Storage and Processing, 9, No. 3: 73 (2007) (in Ukrainian). 
5. J. Zhang, M. Gecevičius, M. Beresna, and P. G. Kazansky, Phys. Rev. Lett., 112, No. 3: 033901 (2014).

6. A. A. Kryuchyn, V. V. Petrov, S. O. Kostyukevych, K. V. Kostyukevych, A. A. Kudryavtsev, and N. L. Moskalenko, Semiconductor Physics, Quantum Electronics and Optoelectronics, 16, No. 4: 362 (2013).

7. Y. Shimotsuma, K. Hirao, J. Qiu, and K. Miura, J. Non-Crystalline Solids, 352: 646 (2006).

8. V. V. Petrov, A. A. Kryuchyn, I. V. Gorbov, I. O. Kossko, and S. O. Kostyukevych, Semiconductor Physics, Quantum Electronics and Optoelectronics, 12, No. 4: 399 (2009).

9. A. A. Uglov, L. M. Anishenko, and S. E. Kuznetsov, Adgezionnaya Sposobnost Plenok [Adhesive Ability of Films] (Moscow: Radio i Svyaz: 1987) (in Russian).

10. O. S. Heavens, J. Phys. Radium, 11, No. 7: 355 (1950).

11. V. G. Kravets, L. V. Poperenko, and D. Yu. Manko, J.Appl. Spectr., 77, No. 2: 242 (2010). 